\title{
THE NESTING HABITS OF BOMBUS MEDIUS CRESSON, THE MEXICAN BUMBLEBEE.
}

\author{
By PhIL RaU,
}

Kirkwood, Missouri.

Specimens of this bumblebee were collected at flowers at Cordoba and Jalapa in the State of Vera Cruz. At Tamazunchale, S. L. P., four nests were found among the dense growth of weeds in an abandoned banana field; these were pointed out to me by Mr. Olivarez, the manager of the El Sol Tourist Courts. Two of these nests were dug up on the night of July 7, 1940. Since Dr. T. H. Frison of the Illinois Natural History Survey (who kindly identified the bumblebees for me) writes that nothing is known of the life history of this species, the data of these two nests are herewith presented.

Both colonies were in slight cavities in the ground which evidently had been rodents nests, containing masses of fine roots, bits of narrow stems evenly cut, parts of leaves, and excrement of mice. There were no special galleries leading into the nests, but the comb was brought to view by brushing away the surface material to a depth of an inch and a quarter to an inch and three quarters.

When disturbed, the bees let out a steady, musical hum which, while not as loud as that of our Missouri B. americanorum, could be heard from a distance of ten to twelve feet. Their sting, while quite painful, is not so severe or lasting as that of its American relative. The workers of $B$. medius are smaller than those of $B$. americanorum, but the queens are almost equal in size.

An examination of the two nests, designated as A and B, revealed the following data. Nest $A$ had one old queen, with wings badly frayed, and nest $B$ had two queens, an old one with the tips of the wings badly damaged, and a young one with perfect wings and portions of the pubescence of a lighter, cleaner yellow. There were no males in either nest. 
The number of workers in these colonies (and it is presumed that all the workers were at home, since the nests were taken at night) were 27 in Nest A and 63 in Nest B. ${ }^{1}$

The number of empty cocoons from which workers had emerged numbered 39 and 84 respectively. These figures are highly interesting from the standpoint of mortality of the workers, for we find that the colony with 27 workers had actually given birth to 39 , and the colony with 63 workers had produced 84. The two colonies therefore had lost 12 and 21 workers respectively. Worker bumblees must brave the vicissitudes of enemies and inclement environmnt in their foraging expeditions, and one expects a certain portion of the population to fare ill, but whether the figures given above are much or little one cannot tell, since there is little comparative data at hand. However, in a population study of one $B$. americanorum colony made at the end of the season in Missouri, the mortality was much less than in these nests, for out of 137 workers born in the colony during the season, 131 survived until near the end of the season. ${ }^{2}$

The pupæ and quiescent larvæ within cocoons numbered 17 in Nest A and 69 in Nest B, and young feeding larvæ (usually a small number of larvæ within a ball-like mass of pollen-paste) numbered five ( 2 in one mass and 3 in the other) in Nest A, and three (all in one mass) in Nest B.

The eggs were placed in small clusters in hollow spaces in the interior of the pollen-paste balls. These were without openings, and measured roughly about one-quarter inch in diameter, and were attached to cocoons and other objects in the nest. They were designed to serve as food for the tiny larvæ when they hatched from the eggs. In Nest A were four such masses, containing 8, 7, 6 and 4 eggs respectively. In Nest B were two balls, containing 2 and 6 eggs.

The total potential populations of these nests, including queens, workers, larvæ and eggs, were 75 and 145.

As is usual with bumblebees, pollen and nectar are stored in vats made of wax-like material; both are also stored in old cocoons from which the bees have emerged. Sometimes the cocoons are enlarged for this purpose by placing an

113 of Nest B emerged from their cocoons in my jars during the following few days.

2Entom. News, 52: 70-74, 1941. 
addition of this wax-like substance on the rim of the cup. Thus in Nest B, 16 empty cocoons which had been used at one time or another as storage vats had had their capacity increased by extensions which varied from one-eighth inch to three-fourths inch. Two old cocoons completely filled with honey were tightly sealed with lids of wax. The largest pot, constructed entirely of wax, was in Nest B, and measured one inch in height by a half-inch in diameter. In both nests were several of these cocoon-vats that had remnants of pollen or honey, and in some cases they were half full of food at the time the nests were taken. In both nests some of the old cocoons had been partly bitten away, evidently by the workers, but why it had been done or what the bits of material had been used for is not known.

There were no males in the nests, neither were there any parasites or messmates, except for an unknown moth larva and an unknown moth cocoon among the cocoons.

On the whole, except for the tendency to slightly larger colonies, the life history of Bombus medius differs but little from that of our Missouri Bombus americanorum. 

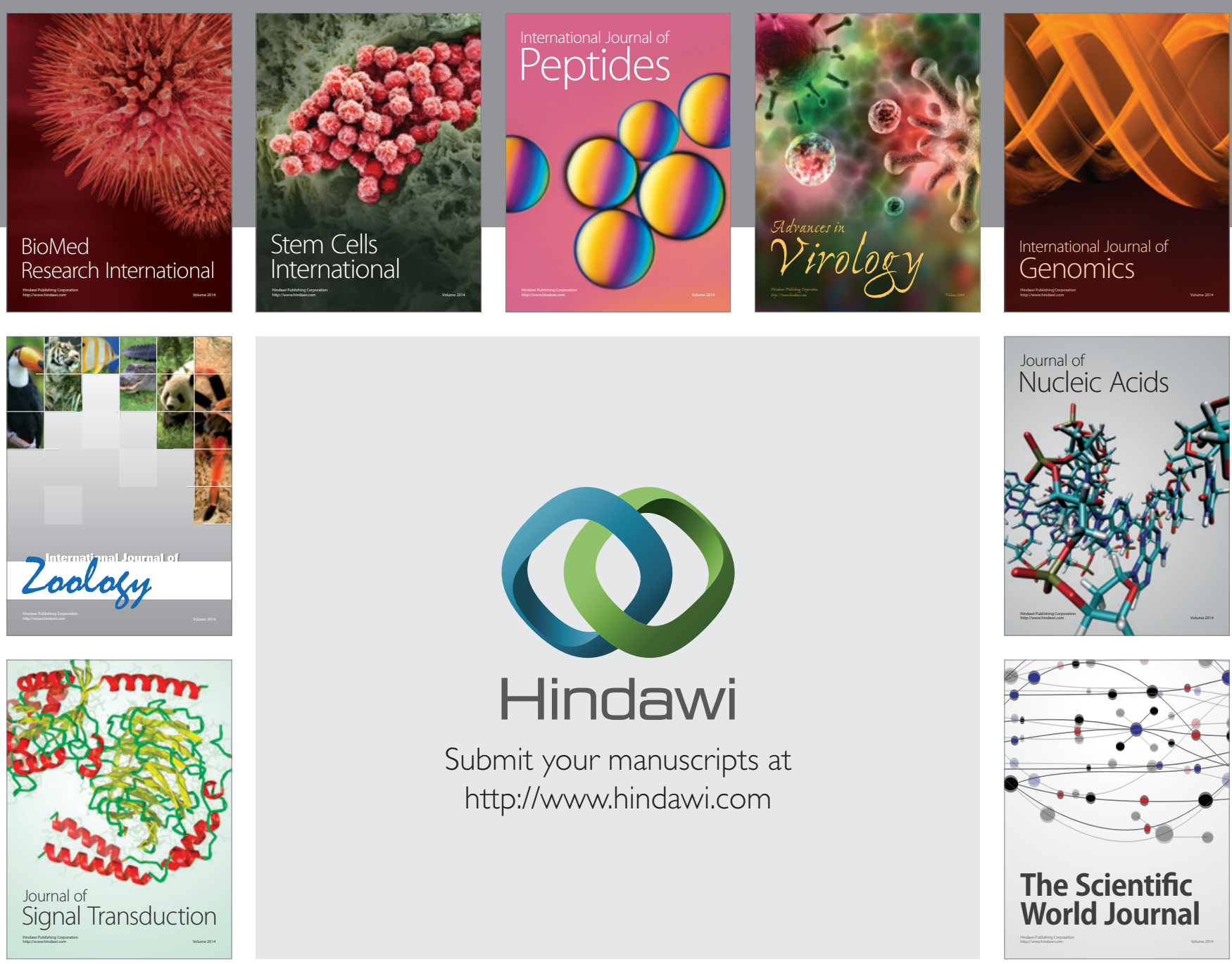

Submit your manuscripts at

http://www.hindawi.com
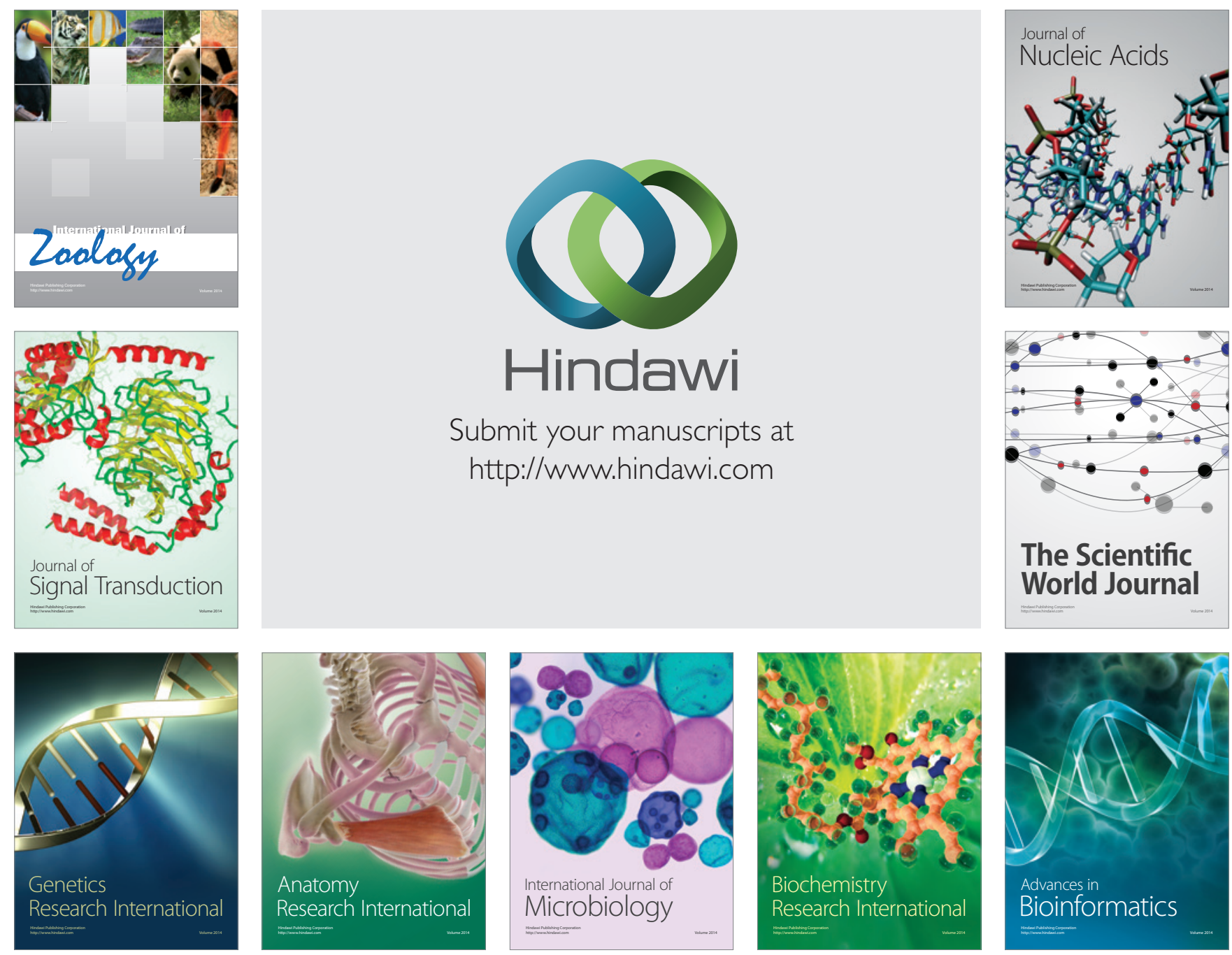

The Scientific World Journal
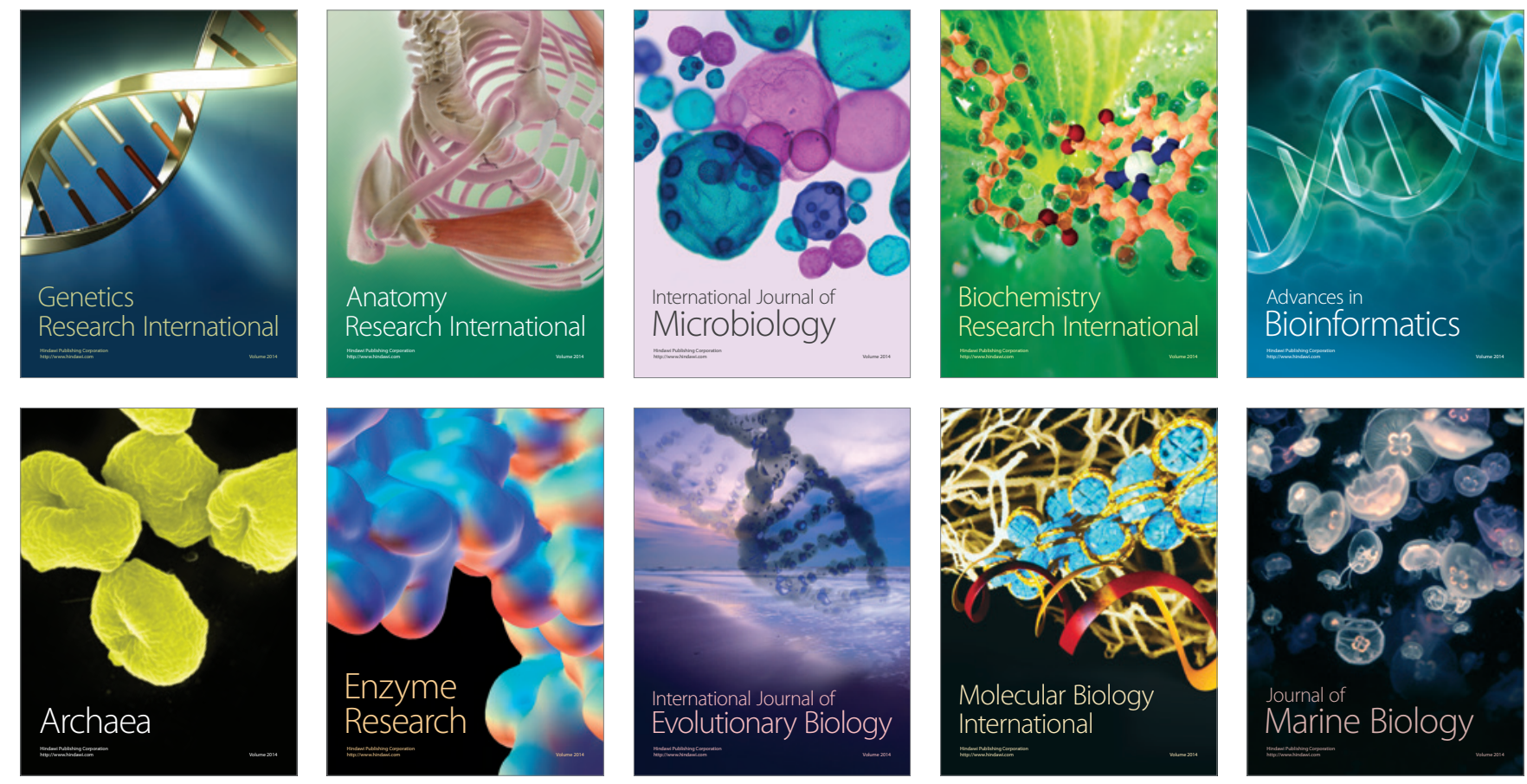